\title{
Resource allocation during COVID-19: A focus on vulnerable populations
}

\author{
C de V Castelyn, ${ }^{1,2}$ MDiv; I M Viljoen, ${ }^{2}$ BPharm; A Dhai, ${ }^{3}$ MB ChB, FCOG (CMSA), LLM, PG Dip Int Res Ethics, PhD; \\ M S Pepper, ${ }^{2}$ MB ChB, PhD, MD, PD \\ ${ }^{1}$ Centre for Ethics and Philosophy of Health Sciences, Faculty of Health Sciences, University of Pretoria, South Africa \\ 2 Institute for Cellular and Molecular Medicine, Department of Immunology, and SAMRC Extramural Unit for Stem Cell Research and Therapy, \\ Faculty of Health Sciences, University of Pretoria, South Africa \\ ${ }^{3}$ School of Clinical Medicine, Faculty of Health Sciences, University of the Witwatersrand, Johannesburg, South Africa
}

\section{Corresponding author:M S Pepper (michael.pepper@up.ac.za)}

\begin{abstract}
South Africa (SA) is a country of contrasts, with abundant resources, hard-won civil rights and a diverse population. Woven into the fabric of our society is a large divide between its poorest and its wealthiest members. In this article we highlight the vulnerabilities in our society that have been amplified by the COVID-19 crisis. Based on recent projections, it is very likely that the healthcare system will be overwhelmed. We acknowledge the recognition by government and civil society of these vulnerabilities, and note that difficult decisions will need to be made with regard to resource allocation. Our plea, however, is to ensure that human dignity and the principle of distributive justice are maintained, and that when difficult decisions are made, vulnerable people do not suffer disproportionately. Furthermore, it is of great concern that there is no national directive guiding resource allocation, prioritisation and triage decisions in both public and private hospitals. The Health Professions Council of SA should, as a matter of urgency, issue guidance on priority-setting and triage decisions in the context of COVID-19, based on distributive justice principles.
\end{abstract}

S Afr J Bioethics Law 2020;13(2):83-86. https://doi.org/10.7196/SAJBL.2020.v13i2.730

The economic, social and health impacts of the COVID-19 pandemic have brought into sharp focus matters related to the allocation of diagnostic tests, personal protective equipment (PPE) and critical care equipment such as ventilators.

Franklin Roosevelt said that 'the test of progress is not whether we add more to the abundance of those who have much; it is whether we provide enough for those who have too little. [1]

In midst of a global pandemic where there is 'not enough to go around' and an alarming escalation in the loss of life, the way in which we provide for those who have too little will determine how we look back on this crisis in the future. The COVID-19 pandemic, in which to date more than 7 million people have tested positive and more than 400000 lives have been lost, ${ }^{[2,3]}$ is exposing the world's inequalities. ${ }^{[4]}$ Throughout this pandemic, it has been shown that among those disproportionately affected are people on the margins of society, often living below the breadline. ${ }^{[5-7]}$ For example, in some US states, black and Hispanic minority groups account for around $40 \%$ of deaths, yet represent only $14-15 \%$ of the population. ${ }^{[6]}$ The World Bank estimates that the proportion of people living on less than USD5.50 a day could rise to $42 \%$ as a consequence of the global pandemic. ${ }^{[8]}$ At the very heart of this unfolding tragedy, in addition to socioeconomic factors, lies the matter of the way in which resources are being allocated.

\section{Current situation}

The Hastings Centre ${ }^{[9]}$ and Nuffield Council, ${ }^{[10]}$ as well as others, ${ }^{[1,12]}$ have released ethical frameworks to guide institutions in decisionmaking. A diverse group of medical health professionals, scientists, academics and advocates from 50 countries, in an open letter to the World Health Organization (WHO), have proposed the establishment of a Global Health Equity Task Force to ensure equitable allocation of resources at a global level, with a specific focus on vulnerable people. ${ }^{[13]}$ However, South Africa (SA) faces unique challenges, and therefore requires unique local guidance..$^{[14,15]}$ Of a population of close to 60 million, $13.6 \%{ }^{[16]}$ of its citizens live in informal settlements, and 6.7 million South Africans were unemployed before the lockdown. ${ }^{[17]}$ Lack of infrastructure in rural settings, and crowding in informal settlements, make implementation of preventive measures such as social distancing and self-isolation almost impossible. ${ }^{[3]}$ SA also has large groups of people living with comorbidities. In addition to noncommunicable diseases such as obesity, diabetes and hypertension, there are an estimated 7.7 million people living with $\mathrm{HIV}_{1}{ }^{[18]}$ and 2.5 million with tuberculosis. ${ }^{[19]}$

Making decisions in terms of allocating limited resources is not new to $S A_{1}^{[20,21]}$ and critical discussions on resource allocation in both the public and private healthcare systems are ongoing. Based on current models, the healthcare system will be overwhelmed. ${ }^{[22]}$ The extent of resource shortages will greatly depend on the way in which the outbreak evolves. ${ }^{[22]}$ It is estimated that there will be a shortage of between 20000 and 35000 intensive care unit (ICU) beds between June and November, and a shortage of between 75000 and 90000 general hospital beds in the same period. ${ }^{[22]}$ Recent research indicates that the clinical outcome (based on disability-adjusted years) and cost-effectiveness of general beds is better than that of ICU beds. These findings may or may not influence whether the procurement of 
ICU beds will be prioritised. ${ }^{[23]}$ It is therefore of great concern that there is no national directive guiding resource allocation, prioritisation and triage decisions in both public and private hospitals. This lack of clear guidance from government could have dire consequences for the people who are most vulnerable.

The first COVID-19 case in SA was confirmed on 5 March 2020. ${ }^{[24]}$ President Cyril Ramaphosa announced a national state of disaster on 15 March. ${ }^{[25]}$ A lockdown was consequently implemented on 27 March to curb the spread of the virus and to flatten the curve. On 9 April, President Ramaphosa extended SA's lockdown for a further 2 weeks. ${ }^{\left[{ }^{[2]}\right.}$ From the outset, the impact on society's most vulnerable people has been acknowledged by the President. As the economy becomes increasingly fragile, so do those who are most vulnerable. The President released an additional ZAR20 billion into the health budget. On 24 May he continued to implement an easing of the lockdown in five phases, ${ }^{[27]}$ although, as the nation moved to level 3 on 1 June, and large sectors of the economy are re-opening, ${ }^{[27]}$ the susceptibility of vulnerable people remains.

It is well recognised that vulnerable people become even more vulnerable during pandemics. ${ }^{[28]}$ The $\mathrm{WHO}^{[29]}$ defines vulnerability as the 'degree to which a population, individual or organisation is unable to anticipate, cope with, resist and recover from the impacts of disasters. This definition may, however, need to be further refined according to context. ${ }^{[30]}$ For example, the Gauteng City-Region Observatory ${ }^{[31]}$ mapped vulnerability in the SA province of Gauteng by identifying six factors that increase health and social vulnerability during an outbreak or broader shutdown. These are pre-existing poor health status, pre-existing relevant health conditions, difficulty accessing healthcare, no access to medical aid, hunger and difficulty in saving money. ${ }^{[3]}$ Homeless people, displaced refugees, the elderly, disabled people and women in crisis are among those who usually fall through the cracks, and who, already facing huge challenges, experience heightened distress. Section 2(c)(iv) of the National Health Act No. 61 of 2003 legislates that vulnerable groups such as 'women, children, older persons and persons with disabilities' need to be protected, and their rights promoted. ${ }^{[32]}$

These rights include the right to healthcare, as protected by section 27(1) of the SA Constitution. ${ }^{[33]}$ Although this obliges the state to take all reasonable legislative steps and other measures to realise this access, the state's obligation in this regard is limited to its available resources. Section 2(a)(ii) of the National Health Act affirms that the best possible healthcare services must be provided by the state within its available resources. The best possible healthcare services for all is the highest attainable standard. ${ }^{[34,35]}$

\section{Ethical and social issues}

Distributive justice, the core principle of justice as first described by John Rawls in 1971, ${ }^{[36]}$ aims to ensure the fair distribution of limited resources. When resources are limited, ethical frameworks and health professional directives aim to save the most lives by identifying those with the greatest need and the best prognosis. ${ }^{[11,12]}$ Frameworks and directives regarding access to basic healthcare provisions may, however, lose their significance in the context of a pandemic.

The SA Medical Association (SAMA)'s ethical guidance document issued for medical professionals during COVID-19 highlights a triage protocol from the Critical Care Society of SA (CCSSA). ${ }^{[37]}$ This protocol assigns each patient a critical frailty scale (CFS) from 1 to 9 , in which 1 is very fit and 9 terminally ill. ${ }^{[3]}$ The CFS was adopted from the University of Pittsburgh's 'Allocation of scarce critical care resources during a public health emergency: Executive summary' guidelines, dated March 2020. However, this document has been widely criticised, and was replaced with an updated version on 15 April 2020. The updated version does not include the frailty score, but rather focuses on sound ethical principles and sequential organ failure assessment (SOFA) scores. ${ }^{[37]}$ The CCSSA and SAMA guidance documents have, however, not been updated, and both still include the original CFS.

The Health Professions Council of SA (HPCSA) has issued guidance to health practitioners ${ }^{[38]}$ in which they refer to previous guidelines. They do not, however, refer specifically to triage protocols. In their guidelines for withholding and withdrawing care, ${ }^{[39]}$ it is unethical to prolong treatment if the care is not proportional to the determined beneficial outcome. This is, in essence, a consequentialist approach based on futility, and gives little guidance on priority-setting and triage during outbreaks such as the current COVID-19 pandemic.

The SAMA guidelines fulfil a critical function of providing standardised resource allocation guidelines for medical health professionals; however, they are not binding. The HPCSA, as a statutory council, issues nationally binding policies and guidelines. Nevertheless, both the SAMA and HPCSA guidelines have underlying value judgements and/or a moral code. By their very nature, these judgements must value one (quality of) life over another. However, pre-existing inequality in society (consider SA's Gini coefficient ${ }^{[40]}$ ) is exacerbated in times like these. Therefore a utilitarian ethical approach that aims to maximise the most good by saving the most lives and most life years does not factor in socioeconomic factors that influence access to healthcare and general wellbeing. ${ }^{[10,41-43]}$ For example, if central facilities are saturated, this may mean that the most vulnerable in rural areas, i.e. those who are worst off, ${ }^{[12]}$ may not progress beyond their local clinic, and therefore will not have access to critical care services. In contrast, the ethical approach of distributive justice, as espoused by Rawls, seeks to maximise the most good for those who are worst off. ${ }^{[44]}$ Consequently, if these frameworks are narrowly focused only on maximising good, i.e. saving lives, rather than on a multiprinciple approach ${ }^{[12]}$ that includes those who are worst off, distributive justice will fail. It is therefore imperative that nationally binding guidance that incorporates Rawls' distributive justice approach be provided.

Increased social support for poor and vulnerable communities is being implemented, within the limits of government's means, as part of President Ramaphosa's three-part strategy. Mobile testing is being rolled out, infrastructure such as basic sanitary services, including water and handwashing stations, is being installed, food parcels are being distributed, financial assistance is being provided via the Solidarity Fund, and the government's ZAR500 million reliefof-distress social grants have been released. ${ }^{[45]}$ Leilani Farha from the United Nations ${ }^{[46]}$ has reiterated that housing is one frontline response that would curb the spread of the virus for the most vulnerable. Government, the private sector, non-profit organisations, religious communities, social workers and civil society have rallied together and are working tirelessly to provide housing, food and basic hygiene. ${ }^{[47]}$ Other strategies underway by the Department of Human Settlements include the de-densification of informal settlements. ${ }^{[48]}$ However, 
since the onset of the lockdown, several of these initiatives have met with challenges. Distribution of food parcels, for example, has been inconsistent. At Strandfontein homeless shelter, ${ }^{[7,49]}$ people have been displaced without adequate support and basic services. Some homeless people are on methadone treatment; it is questionable whether they will be able to access their healthcare needs during this unfolding crisis. And the long queues of people collecting food parcels and social grants defy the principles of social distancing.

\section{Conclusion}

The way in which morally distressing challenges are addressed and implemented is a critical indicator of humanity's compassion. ${ }^{[50]}$ The principle of human dignity and the Bill of Rights, as enshrined in our Constitution, must be upheld. Distributive justice must be implemented to the best of our ability, and we should avoid exacerbating inequality by implementing narrowly focused frameworks and directives. Community engagement should be facilitated when designing these ethical frameworks, to empower decision-making through a diversity of voices in society. ${ }^{[51]}$

Additionally, and in line with the principle of solidarity, this should be a time of gracious giving and sharing of resources (within clinically safe practices), including the public and private healthcare systems working together. ${ }^{[52]}$ At a clinical level, where triage will inevitably occur, these criteria should aim to mitigate discrimination on the basis of socioeconomic grounds, and should only be based on clinical criteria that adhere to a predetermined set of standards. Limited training and a shortage of PPE has hindered the important work of community health workers, who on a daily basis form the critical link between the community and other healthcare professionals (such as nurses and doctors). ${ }^{[5,54]}$ They must be adequately trained and empowered to provide education and basic healthcare advice on COVID-19. If these measures are not implemented, we could see injustice in the form of human rights violations. ${ }^{[4]}$

In the words of the global visionary leader Barack Obama, 'We can't deny that racial and socioeconomic factors are playing a role in who is being hit the hardest by the virus. It's a reminder for our policymakers to keep our most vulnerable communities at the forefront when making decisions.[5] Vulnerable populations are those who, as a result of several factors, often beyond their control, are unable to cope in a disaster such as the one we are currently facing. Limited infrastructure and resources may result in greater suffering. Their basic human dignity and rights, including access to healthcare, are in the balance. When decisions are made at institutional levels, moral codes and value judgements inevitably come into play. It is essential that national standardised guidance is provided on how resources should be allocated, so that those who have less are not overlooked and do not suffer disproportionately. The HPCSA should, as a matter of urgency, issue ethical guidance, based on distributive justice principles, on priority-setting and triage decisions in the context of the COVID-19 pandemic.

Acknowledgements. The authors would like to acknowledge the advice provided by Dr Marietjie Botes, who was consulted during the revision of this manuscript.

Author contributions. CdeVC drafted the first version of the manuscript and edited throughout; IMV was involved in initial discussions and edited the manuscript; AD provided input and edited the manuscript
MSP initiated the project, guided its realisation and edited the manuscript.

Funding. CdeVC holds the joint Department of Science and Technology and National Research Foundation Doctoral Innovation Scholarship (grant no. SFH191127494634). MSP is funded by the SA Medical Research Council and the University of Pretoria (through the Institute for Cellular and Molecular Medicine).

Conflicts of interest. None.

1. Persad G, Wertheimer A, Emanuel EJ. Principles for allocation of scarce medical interventions. Lancet 2009;373(9661):423-431. https://doi.org/10.1016/S01406736(09)60137-9

2. Worldometers. COVID-19 Coronavirus pandemic. https://www.worldometers. info/coronavirus/ (accessed 9 June 2020).

3. Adam S, Lindeque G, Soma-Pillay P. Bioethics and self-isolation: What about lowresource settings? S Afr Med J 2020;110(5):350-352. https://doi.org/10.7196/ SAMJ.2020.v110i5.14733

4. Williams DR, Cooper LA. COVID-19 and health equity - a new kind of "herd immunity". JAMA 2020;323(24):2478-2480. https://doi.org/10.1001/ jama.2020.8051

5. Wang Z, Tang K. Combating COVID-19: Health equity matters. Nat Med 2020 26(4):458. https://doi.org/10.1038/s41591-020-0823-6

6. Eligon J, Burch AD, Searcey D, et al. Black Americans face alarming rates of coronavirus infection in some states. New York Times, 4 April 2020. https:// www.nytimes.com/2020/04/07/us/coronavirus-race.html (accessed 14 April 2020).

7. Van Dorn A, Cooney R, Sabin M. COVID-19 exacerbating inequalities in the US. Lancet;395(10232):1243-1244. https://doi.org/10.1016/S0140-6736(20)30893-X

8. World Bank. Poverty. Washington, DC: World Bank, 2020. https://www.worldbank. org/en/topic/poverty/overview (accessed 14 April 2020).

9. Berlinger N, Wynia M, Powell T, et al. Ethical framework for health care institutions responding to novel coronavirus SARS-CoV-2 (COVID-19) guidelines for institutional ethics services responding to COVID-19. Managing uncertainty, safeguarding communities, guiding practice, 2020. New York: Hastings Center, March 162020. www.thehastingscenter.org/ethicalframeworkcovid19 (accessed 14 April 2020).

10. Nuffield Council on Bioethics. Rapid policy briefing: Ethical considerations in responding to the COVID-19 pandemic. London: Nuffield Council on Bioethics, 2020.

11. Truog RD, Mitchell C, Daley GQ. The toughest triage - allocating ventilators in a pandemic. N Engl J Med 2020;382(21):1973-1975. https://doi.org/10.1056/ NEJMp2005689

12. Emanuel EJ, Persad G, Upshur R, et al. Fair allocation of scarce medical resources in the time of COVID-19. N Engl J Med 2020;382(21):2049-2055. https://doi.org/ 10.1056/NEJMsb2005114

13. Chiriboga D, Garay J, Buss P, et al. Health inequity during the COVID-19 pandemic: A cry for ethical global leadership. Lancet;395(10238):1690-1691. https://doi. org/10.1016/S0140-6736(20)31145-4

14. Cash R, Patel V. Has COVID-19 subverted global health? Lancet 2020;395:(epub ahead of print). https://doi.org/10.1016/S0140-6736(20)31089-8

15. Behrens KG, University of the Witwatersrand, Johannesburg. Clinical ethical challenges in the COVID-19 crisis in South Africa. Wits J Clin Med 2020;2(SI):29.

16. Statistics South Africa. General Household Survey 2017. Pretoria: StatsSA, 2017.

17. Department of Statistics, South Africa. Quarterly Labour Force Survey Quarter 3: 2019. Statistical Release. Pretoria: Department of Statistics, 2019.

18. Boffa J, Mhlaba T, Sulis G, et al. COVID-19 and tuberculosis in South Africa: A dangerous combination. S Afr Med J 2020;110(5):341-342. https://doi. org/10.7196/SAMJ.2020.v110i5.14747

19. World Health Organization. Global Tuberculosis Report 2019. Geneva: World Health Organization, 2019.

20. Jones-Bonofiglio K, Nortje N. A policy and decision-making framework for South African doctors during the COVID-19 pandemic. S Afr Med J 2020;110(7):(epub ahead of print). https://doi.org/ 10.7196/SAMJ.2020.v110i7.14822

21. Moodley K. Tough choices about who gets ICU access: The ethical principles guiding South Africa. The Conversation, 2020. https://theconversation.com/ tough-choices-about-who-gets-icu-access-the-ethical-principles-guidingsouth-africa-135227 (accessed 14 May 2020).

22. South African COVID-19 Modelling Consortium. Estimating cases for COVID-19 in South Africa. Long-term national projections. Pretoria: National Institute for Communicable Diseases, 2020. https://www.nicd.ac.za/wp-content/ uploads/2020/05/SACovidModellingReport_NationalLongTermProjections_ Final-1.pdf (accessed 6 May 2020). 
23. MOSAIC. A model to assess the cost-effectiveness of ICU strategies for the South African COVID-19 response. Cape Town: Health Economics Unit, Alan J Flisher Centre for Public Mental Health (UCT) and Health Systems Research Unit (SAMRC), 2020.

24. National Institute for Communicable Diseases. First case of COVID-19 coronavirus reported in SA. Pretoria: NICD, 2020. https://www.nicd.ac.za/first-case-of-covid19-coronavirus-reported-in-sa/ (accessed 11 June 2020).

25. Department of Co-operative Governance and Traditional Affairs, South Africa. Declaration of a national state of disaster. Government Gazette No. 43096, 2020. https://www.gov.za/sites/default/files/gcis_document/202003/43096gon313. pdf (accessed 15 March 2020).

26. Ramaphosa C. Message by President Cyril Ramaphosa on COVID-19 pandemic. 9 April 2020. http://www.thepresidency.gov.za/speeches/message-presidentcyril-ramaphosa-covid-19-pandemic-0 (accessed 17 April 2020).

27. Ramaphosa C. Address by President Cyril Ramaphosa on South Africa's response to the coronavirus pandemic. Union Buildings, Tshwane, 24 May 2020. http:// www.thepresidency.gov.za/speeches/address-president-cyril-ramaphosasouth-africa's-response-coronavirus-pandemic\%2C-union-buildings\%2Ctshwane-0 (accessed 27 May 2020).

28. International Bioethics Committee, World Commission on the Ethics of Scientific Knowledge and Technology. Statement on COVID-19: Ethical considerations from a global perspective. https://unesdoc.unesco.org/ark:/48223/pf0000373115 (accessed 27 May 2020).

29. Wisner B, Adams J, World Health Organization (eds). Environmental Health in Emergencies and Disasters: A Practical Guide. Geneva: WHO, 2002. https://apps. who.int/iris/bitstream/handle/10665/42561/9241545410_eng.pdf?sequence=1 (accessed 4 March 2020).

30. Lancet. Redefining vulnerability in the era of COVID-19. Lancet 2020;395(10230):1089. https://doi.org/10.1016/S0140-6736(20)30757-1

31. De Kadt J, Gotz G, Hamman C, et al. Mapping vulnerability to COVID-19 in Gauteng. Gauteng City-Region Observatory GCRO Map of the Month. Johannesburg: GCRO, 2020. https://www.gcro.ac.za/outputs/map-of-themonth/detail/mapping-vulnerability-to-covid-19/ (accessed 27 May 2020).

32. South Africa. National Health Act No. 61 of 2003.

33. Constitution of the Republic of South Africa. 1996.

34. World Health Organization. Constitution. Geneva: WHO, 1948. http://apps.who. int/gb/bd/PDF/bd47/EN/constitution-en.pdf?ua=1 (accessed 11 June 2020).

35. United Nations. International Covenant on Economic, Social and Cultural Rights, 1966. Geneva: UN, 1966. https://www.ohchr.org/Documents/Professionallnterest/ cescr.pdf (accessed 11 June 2020).

36. White DB, Katz M, Luce J, et al. Allocation of scarce critical care resources during a public health emergency: Executive summary. Pittsburgh: University of Pittsburgh, 2020. https://ccm.pitt.edu/sites/default/files/UnivPittsburgh_ ModelHospitalResourcePolicy 202004 15.pdf (accessed 27 May 2020).

37. South African Medical Association. The South African Medical Association SARS-CoV-2 (COVID-19) guidance for managing ethical issues. https://www. samedical.org/files/covid19/doctor_resource/SAMA_Ethics\%20Guidance\%20 COVID-19\%20Ethics_2020\%207\%20_Apr.pdf (accessed 8 April 2020).

38. Health Professionals Council of South Africa. COVID-19 outbreak in South Africa: Guidance to health practitioners. Pretoria: HPCSA, 2020. https://www.hpcsa. co.za/Uploads/Events/Announcements/HPCSA_COVID-19_guidelines_FINAL. pdf (accessed 27 May 2020).

39. Health Professions Council of South Africa. Guidelines for withholding and withdrawing of treatment. Pretoria: HPCSA, 2016. https://www.hpcsa.co.za/ Uploads/Professional_Practice/Conduct\%20\%26\%20Ethics/Booklet $\% 20$ 7\%20Guidelines\%20withholding\%20and\%20withdrawing\%20treatment $\% 20$ September\%202016.pdf (accessed 29 May 2020).

40. Statistics South Africa. Inequality trends in South Africa: A multidimensional diagnostic of inequality. Pretoria: StatsSA, 2019. http://www.statssa.gov.za/ publications/Report-03-10-19/Report-03-10-192017.pdf (accessed 13 April 2020).
41. Goodwin J, Liddell K, Martin S, et al. Allocating medical resources in the time of COVID-19. N Engl J Med 2020;383(22):e79. https://doi.org/10.1056/ NEJMc2009666

42. Burgess R. COVID-19 mental-health responses neglect social realities. Nature 4 May 2020:d41586-020-01313-9. https:/doi.org/10.1038/d41586-020-01313-9

43. Cleveland Manchanda E, Couillard C, Sivashanker K. Inequity in crisis standards of care. N Engl J Med 2020;383:e16. https://doi.org/10.1056/NEJMp2011359

44. Olsen JA. Theories of justice and their implications for priority setting in health care. J Health Econ 1997;16(6):625-639.

45. Ramaphosa C. Statement by President Cyril Ramaphosa on further economic and social measures in response to the COVID-19 epidemic. 21 April 2020. http://www.thepresidency.gov.za/speeches/statement-president-cyrilramaphosa-further-economic-and-social-measures-response-covid-19 (accessed 28 May 2020).

46. Farha L. 'Housing the front-line defence against the COVID-19 outbreak,' says UN expert. Office of the United Nations High Commissioner for Human Rights, 18 March 2020. https://www.ohchr.org/EN/NewsEvents/Pages/DisplayNews. aspx?News $\mid D=25727 \&$ LangID=E (accessed 18 March 2020).

47. Christensen S. South Africa forced to confront homelessness amid virus lockdown Yahoo News, Agence France Presse (AFP), 3 April 2020. https://news.yahoo.com/ africa-forced-confront-homelessness-amid-virus-lockdown-161131041.htm (accessed 13 April 2020).

48. Pillay K, Singh K. Plans to shrink informal settlements to curb virus. Mercury, 25 March 2020. https://www.iol.co.za/mercury/news/plansto-shrink-informal-settlements-to-curb-virus-45522403 (accessed 25 March 2020)

49. Tembo T. WATCH: Strandfontein homeless shelter described as a 'concentration camp'. Cape Argus, 9 April 2020. https://www.iol.co.za/capeargus/news/watch strandfontein-homeless-shelter-described-as-a-concentration-camp-46502470 (accessed 13 April 2020).

50. Dhai $A$, Veller $M$, Ballot $D$, et al. Pandemics, professionalism and the duty of care: Concerns from the coalface. S Afr Med J 2020;110(6):450-452. https://doi. org/10.7196/SAMJ.2020.v110i6.14901

51. Mosam A, Goldstein S, Erzse a, et al. Building trust during COVID 19: Valuedriven and ethical priority-setting. S Afr Med J 2020;110(6):443-444. https://doi. org/10.7196/SAMJ.2020.v110i6.14893

52. Evans S. SA's healthcare system has only around 3000 critical care hospital beds available ... and it is not enough. News24, 20 March 2020. https://www.news24. com/SouthAfrica/News/sas-healthcare-system-has-only-around-3-000-criticalcare-hospital-beds-available-and-it-is-not-enough-20200320 (accessed 13 April 2020).

53. October A. Discontent among community health workers on the frontlines. Daily Maverick, 3 April 2020. https://www.dailymaverick.co.za/article/2020-04 03-discontent-among-community-health-workers-on-the-frontlines/ (accessed 17 April 2020).

54. Department of Health, KwaZulu-Natal. Community health workers. Durban KZN DoH, 2001. http://www.kznhealth.gov.za/chw.html (accessed 17 April 2020).

55. Obama B. We can't deny that racial and socioeconomic factors are playing a role in who is being hit the hardest by the virus. It's a reminder for our policymakers to keep our most vulnerable communities at the forefront when making decisions. Twitter status, 13 April 2020. https://twitter.com/BarackObama/ status/1249722411781668865 (accessed 13 April 2020).

Accepted 29 June 2020. 